University of Nebraska - Lincoln

DigitalCommons@University of Nebraska - Lincoln

Robert F. Diffendal, Jr., Publications

Natural Resources, School of

Fall 2020

\title{
Tributes to Rick Edwards upon His Retirement
}

Robert Diffendal

Michael Farrell

Michael David Forsberg

Maurice Godfrey

John A. Janovy Jr.

See next page for additional authors

Follow this and additional works at: https://digitalcommons.unl.edu/diffendal

Part of the Geology Commons, Geomorphology Commons, Higher Education Administration Commons, Hydrology Commons, and the Stratigraphy Commons

This Article is brought to you for free and open access by the Natural Resources, School of at DigitalCommons@University of Nebraska - Lincoln. It has been accepted for inclusion in Robert F. Diffendal, Jr., Publications by an authorized administrator of DigitalCommons@University of Nebraska - Lincoln. 


\section{Authors}

Robert Diffendal, Michael Farrell, Michael David Forsberg, Maurice Godfrey, John A. Janovy Jr., Katie Nieland, Linda Pratt, Rebecca S Wingo, David J. Wishart, George E. Wolf, Peter Longo, and John R. Wunder 


\section{Tributes to Rick Edwards upon His Retirement}

Dear Rick,

I understand that you will be retiring from UNL in August. I wanted to express my sadness that you will be leaving the Center for Great Plains Studies, but am glad that you will now be able to perhaps enjoy life even more without having to do the administrative tasks that go with being the director of any organization. I hope to see you from time to time if you stay in Lincoln, but wish you well if you move to be near relatives instead. If you do the latter, I hope that you will find the time to check in with me now and then and let me know how your life is going.

While Director of the CGPS I know that you have done an outstanding job of improving the organization. Both Great Plains Quarterly and Great Plains Research continue to be excellent regional journals. The art museum continues to mount interesting shows and we have had stimulating lectures there over the years. Your work on Great Plains Ecotourism has been wonderful and the Great Plains Book Series has been and continues to be a great success. Your addition of the Platte Basin Timelapse project to the Center's activities, led by Mike Forsberg and Mike Farrell, was inspired. The Black Homesteader project is also a wonderful addition to the Center's work.

I have enjoyed working with you and the other folks in the Center for all the years of your tenure. I hope to be able to continue my activities with the CGPS and hope that the Center will get another fine director.

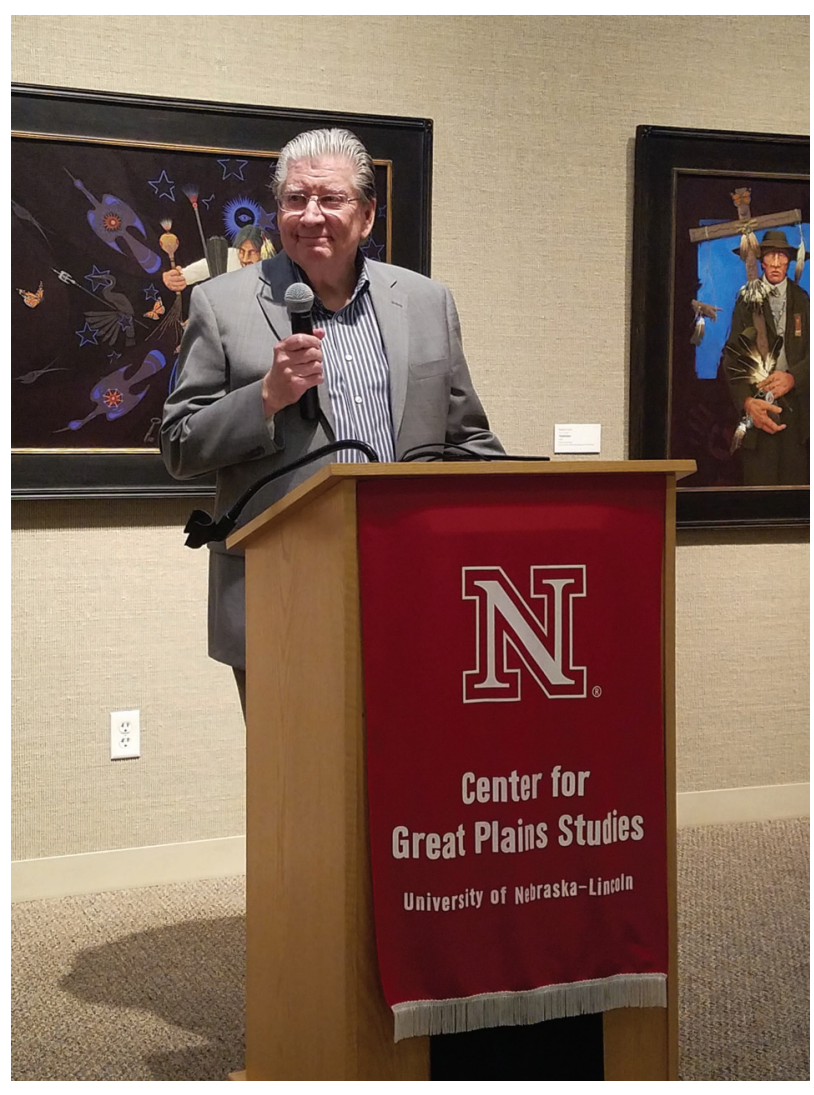

Best regards!

Robert F. Diffendal Jr.

Emeritus Fellow,

Center for Great Plains Studies

Professor Emeritus, Conservation and Survey

Division, School of Natural Resources

Curator of the Invertebrate Paleontology

Collections, University of Nebraska State Museum 


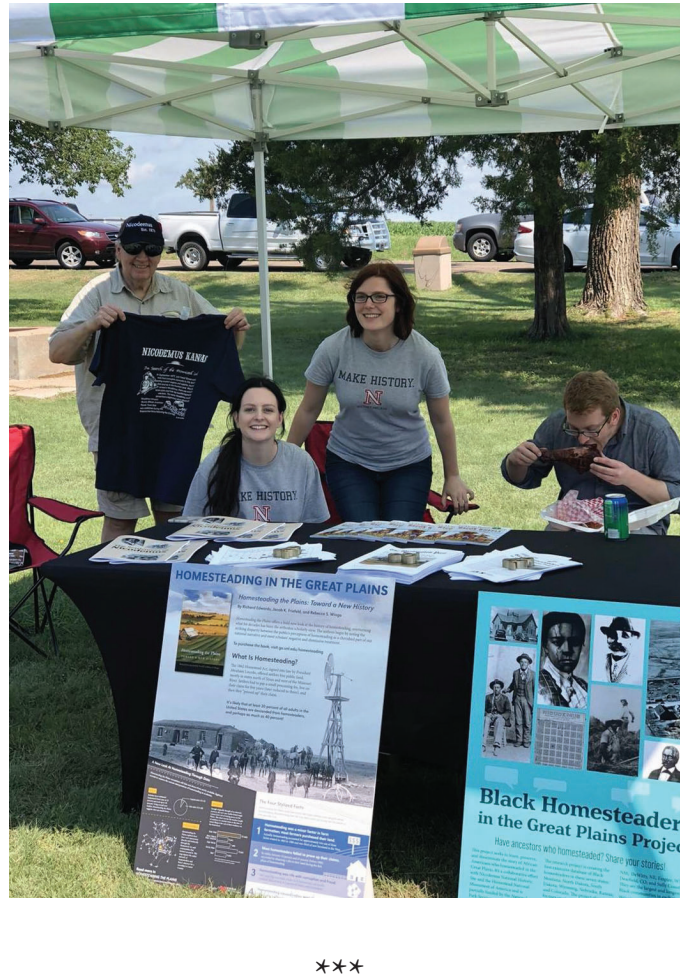

Speaking of Rick Edwards ...

Somewhere there's this great map that shows all the various boundaries of the Great Plains as defined by a wide range of scholars-historians, geographers, soil and grass folks, and so on. It looks like a small child got loose with a crayon and scribbled over and over around the same general outline on a map of the continent.

Nevertheless, it portrays the passion that many people who love this region are willing to put forth in attempting to define it. No one can even agree where it begins and ends. Let alone agree about many of the other vexing details and definitions.

Rick Edwards is a person who is able to hold all this sort of contradictory quibbling in his mind's eye and see beauty: the beauty of disparate points of view coming together through shared love even if not shared definitions.

The Center for Great Plains under Rick has been a haven for folks like me and our Platte Basin Timelapse colleagues as we attempt to scribble our way around the edges of our watershed. We're neither purely art nor science, neither research nor academic, neither staff nor faculty-yet Rick has given us a home for the past few years for which we are ever in his debt!

Michael Farrell

Michael Forsberg

Platte Basin Timelapse
Although my experience with the Center is somewhat limited and only a few years old, it was very quickly and readily apparent that for Rick the Center was a labor of love. It has been a distinct pleasure to know you, and my only regret is that we hadn't been introduced much sooner. Warmest wishes on your retirement!

Maurice Godfrey
Professor
Director, Science Education Partnerships
Associate Editor, Journal of STEM Outreach
$* * *$

Dear Rick:

Congratulations on your retirement, and on a long and distinguished career of service at this university. You have been a model of professional leadership, an example of wisdom, breadth, and intellectual values in a position of major responsibility. The diversity and quality of the Center's activities and publications are remarkable, and that stature is due in no small part to your leadership over the past years. It is a great honor to have been part of the Center's publication program and to work with the staff you have assembled and direct with such care and dignity.

I wish you the best in this next phase of your life. As a good friend of mine once advised, "When you retire, get up, get dressed, and get out of the house every day." It turned out that was excellent advice, easily followed so long as the university was open. I suspect that you have a number of projects that have been filed away, waiting for the freedom to pursue them, so I wish you success in doing so.

Again, congratulations and thank you for your time and work at this university!

Sincerely,

John Janovy Jr.

Varner Professor Emeritus 


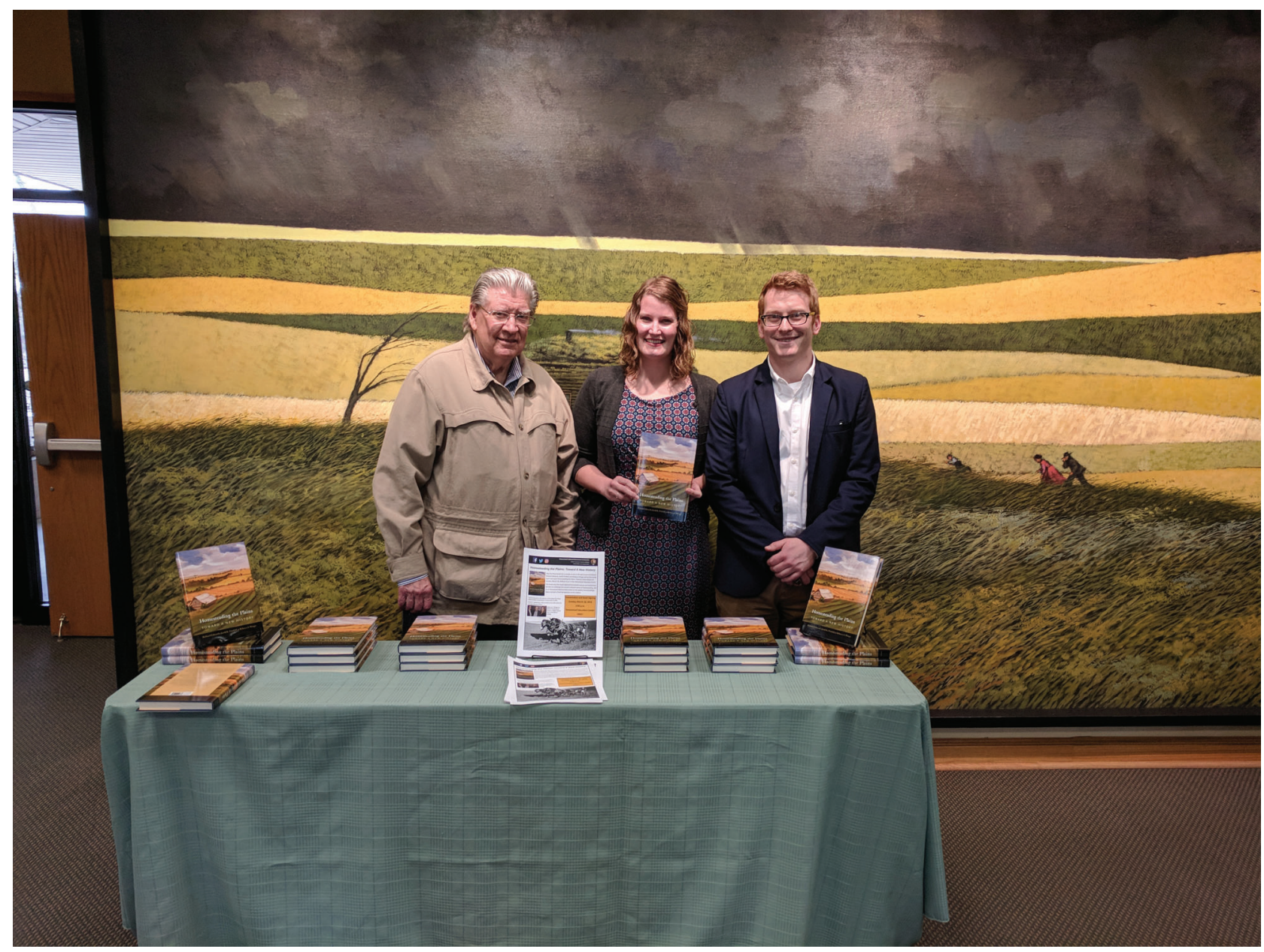

$* * *$

During his time as Director, Rick was always supportive of my ideas, energetic about pursuing new things, and helped me become a better critical thinker and leader in my own position. He sent me on a research trip to Africa, supported an artistic project that led to museum shows and an inclusion of my artwork in the Library of Congress, and made it possible for me to have the time to pursue a master's degree. I'll always appreciate the time we got to be colleagues.

Katie Nieland Assistant Director Center for Great Plains Studies $* * *$

The rarest traits to find combined in a leader are vision and pragmatic know-how. Rick Edwards's career has been marked by both of those things. As Vice Chancellor for Academic Affairs, his vision for what the campus could be, followed by practical planning to get us there, structured most of the best things we did at UNL for the next twenty years. He was gifted in seeing which areas could really be programs of excellence, and he came up with ideas and money to help them do that. I personally know this because I was chair of one of the departments that profited greatly from his help in developing our potential in areas such as Cather studies and creative writing. I learned so much from him in the 1990 and regarded him as my unofficial mentor.

The same fine quality of leadership with vision and practical planning has served the Center for Great Plains Studies the last two decades. His intellectual grasp of life on the Great Plains extended to include everything from the literature and geography to medicine and minority populations. The topics of the annual conferences and his own scholarship are the practical application of that expansive vision of what studies of the Great Plains 


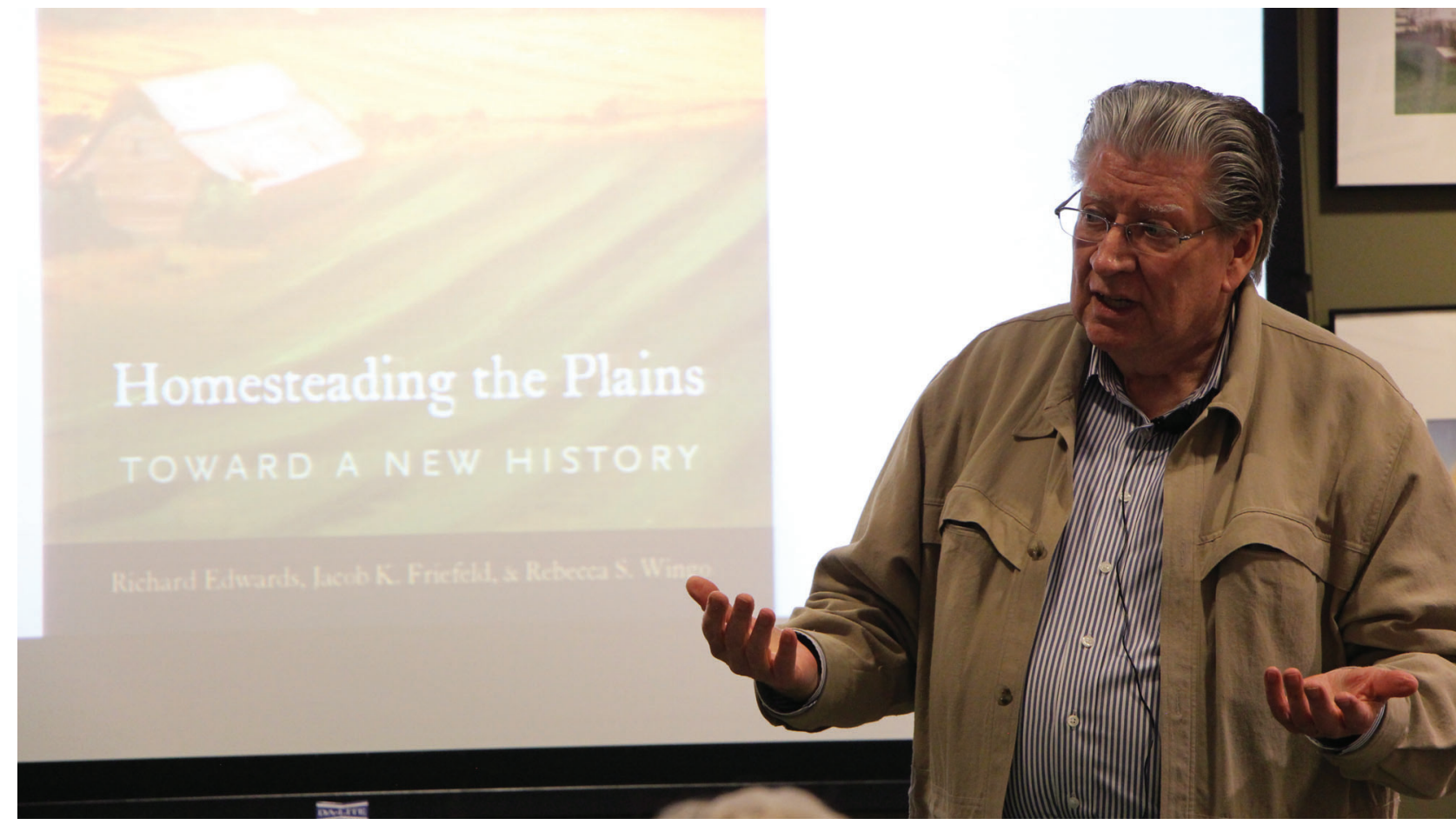

could include. My own commitment to the Center grew as Rick's work made the range of study extend to more and more aspects of this culture that I found interesting and educational. His book series, Discovering the Great Plains, is just one of many projects that have pulled together scholars from a wide variety of fields. Equally noteworthy are the work on the Homestead Act and its consequences and the overlooked lives of Black pioneers.

The guiding ambition of any academic administrator should be to help their faculty become the best they can be, to find ways to enable them to reach those dreams of a successful career that we all hope to have. That is also the way to become the best university that we can be. UNL as a whole and the Center for Great Plains Studies in particular have profited greatly in the last twenty-five years from a leader that always adhered to that principle. His own work stands as an outstanding tribute to him, but the quality of work by others left in his wake is an even deeper testimony to the difference he has made and the distinction he has inspired and facilitated in so many others.

Linda Pratt Emeritus Professor Department of English
I worked closely with Rick on two major initiatives at the Center for Great Plains Studies. The first was born out of a lunch at some small diner in downtown Denver in 2012. Over sandwiches and fries, we sketched out a plan for the Graduate Fellows Program. We created a vibrant work space where interdisciplinary grad students collaborate, learn, work, hold office hours, meet authors and artists, and sometimes even sleep. (Sorry about that! One time someone slept past 5:00 p.m. and set off the alarms.) The program breathed life into a vacant part of the Center.

The second initiative Rick and I collaborated on was the Homestead Project. It started with a summer research assistantship, a road trip to Broken Bow, and very messy data. It turned into an award-winning book, Homesteading the Plains: Toward a New History. Our book forced a reconsideration of the Homestead Act's impact, but Rick's vision didn't stop there. He has continued to push homesteading scholarship forward, from a reexamination of commutations to crucial research on Black homesteaders in Nebraska and the West.

Through it all, Rick was my mentor and my friend. In equal parts, he challenged me, ridiculed me, and sup- 


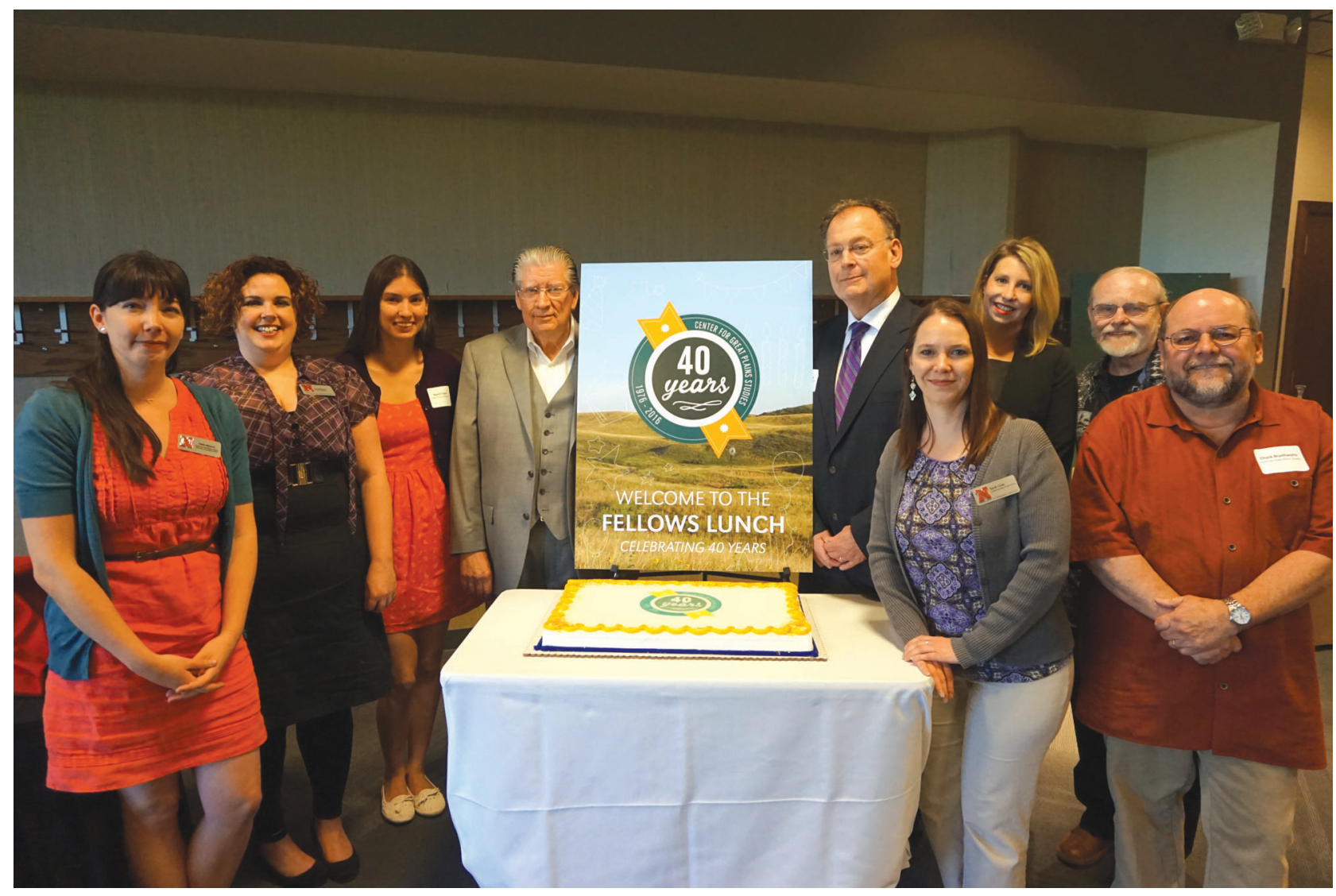

ported me. His belief in me never faltered even when my own did, and that's a gift I'll never forget.

\section{Rebecca S. Wingo \\ Director of Public History and Assistant Professor of History University of Cincinnati}

Under the guidance of Rick Edwards, the Center for Great Plains Studies has gone from strength to strength. Much of this has been driven by his original ideas, such as the small book series, which has gained national attention. Rick has also made sure that the Center's achievements are widely known, not least through display in the New York Review of Books. But he has been not just Director of the Center, he has also contributed to the Center's success through his own scholarship, particularly through his innovative work on homesteading. Finally, I would like to thank Rick for his en- couragement of my own research. He is a fine colleague, and I will miss him.

$$
\begin{array}{r}
\text { David Wishart } \\
\text { Professor of Geography } \\
\text { School of Global Integrative Studies }
\end{array}
$$

Above and beyond all of Rick's obvious outstanding qualities as the Center's Director that merit praise and that others have recorded, I want to emphasize his humanity, his extraordinary skill at imagining himself into the life situations of the people he works with, allowing him not only to grasp our skills and put them to the best use possible but also to perceive or guess at what may at times impede our effectiveness and to respond with an open heart. He is a rarity, and I'm enormously grateful for having known and worked with him.

George Wolf Emeritus Professor Department of English 


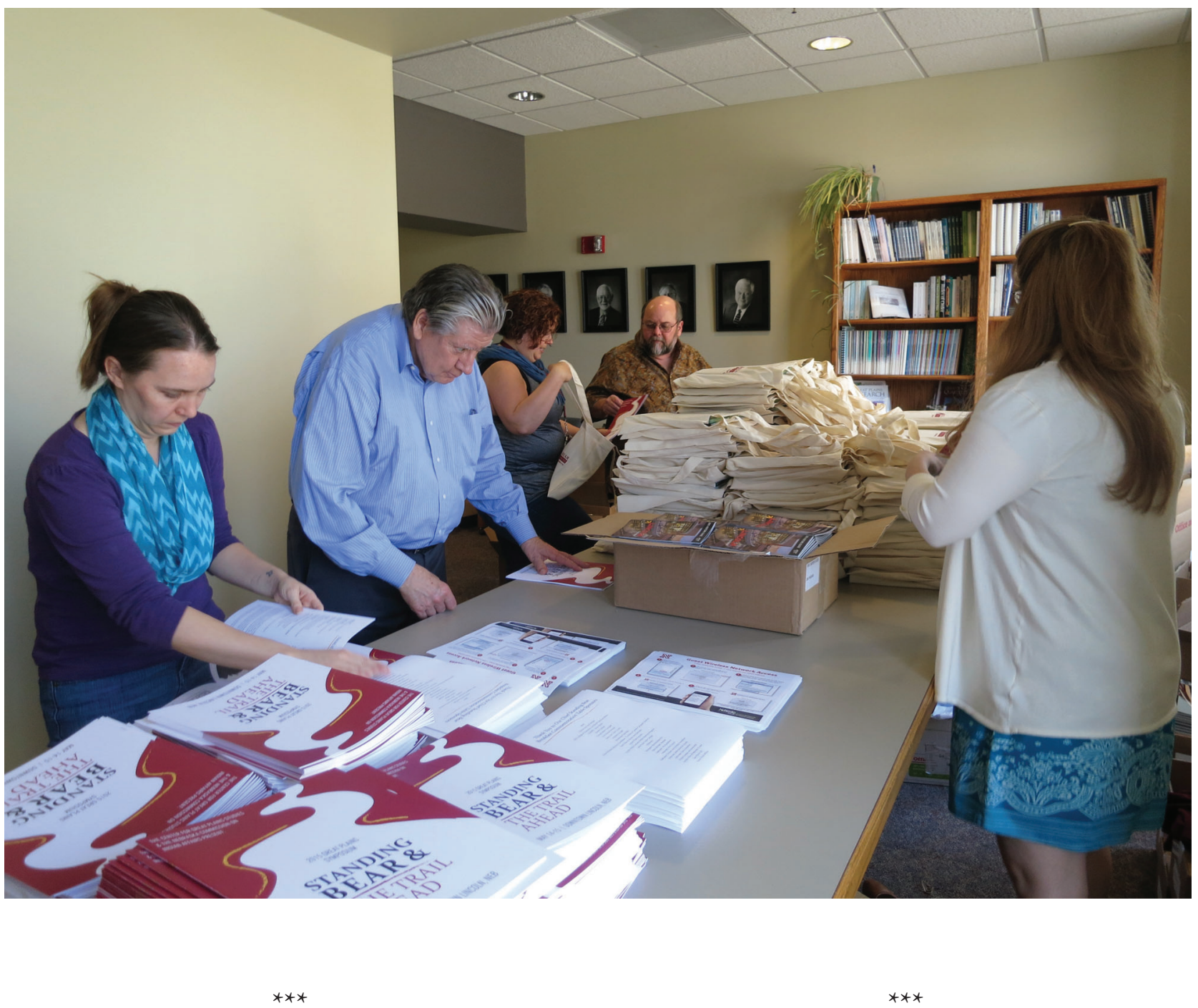

It is with abundant appreciation that I offer brief comments regarding Dr. Richard Edwards, Director of the Center for Great Plains Studies, Professor of Economics, and Senior Vice Chancellor (emeritus). Rick is an accomplished scholar and administrative leader. A Harvard $\mathrm{PhD}$ economist, Rick's keen intellect is fortified in formal training and rooted in a love of place, the Great Plains. His love is enduring and evident as he delivered meaningful symposia, art collections, lectures, special projects, scholarly books, articles, and major research grants. But his love is most evident in his dealings and mentoring of so many colleagues, students, and associates. I, for one, benefited from his love. Thanks, and love to Rick Edwards.

Peter J. Longo Professor of Political Science University of Nebraska at Kearney
It is a special pleasure and honor to be asked to contribute a letter about the directorship of Rick Edwards at the Center for Great Plains Studies on the occasion of his retirement.

For me, as a former director for nine-plus years, I believe Rick's time in leadership of the Center, the most active and strongest interdisciplinary center in the USA, was a time of great accomplishment. There were often significant activities that involved many of the fellows, numerous students, and the general public.

I want to call attention to three of these amazing aspects of Rick's leadership. They include the Center's African initiative; the studies in conjunction with the Homestead National Monument and African American homesteads in particular; and the implementation of graduate programs and fellowships in Great Plains Studies. These activities were fresh, new academic stretches that contributed to the strong, creative reputation of the Center. They are hallmarks of the Center's dynamics. 


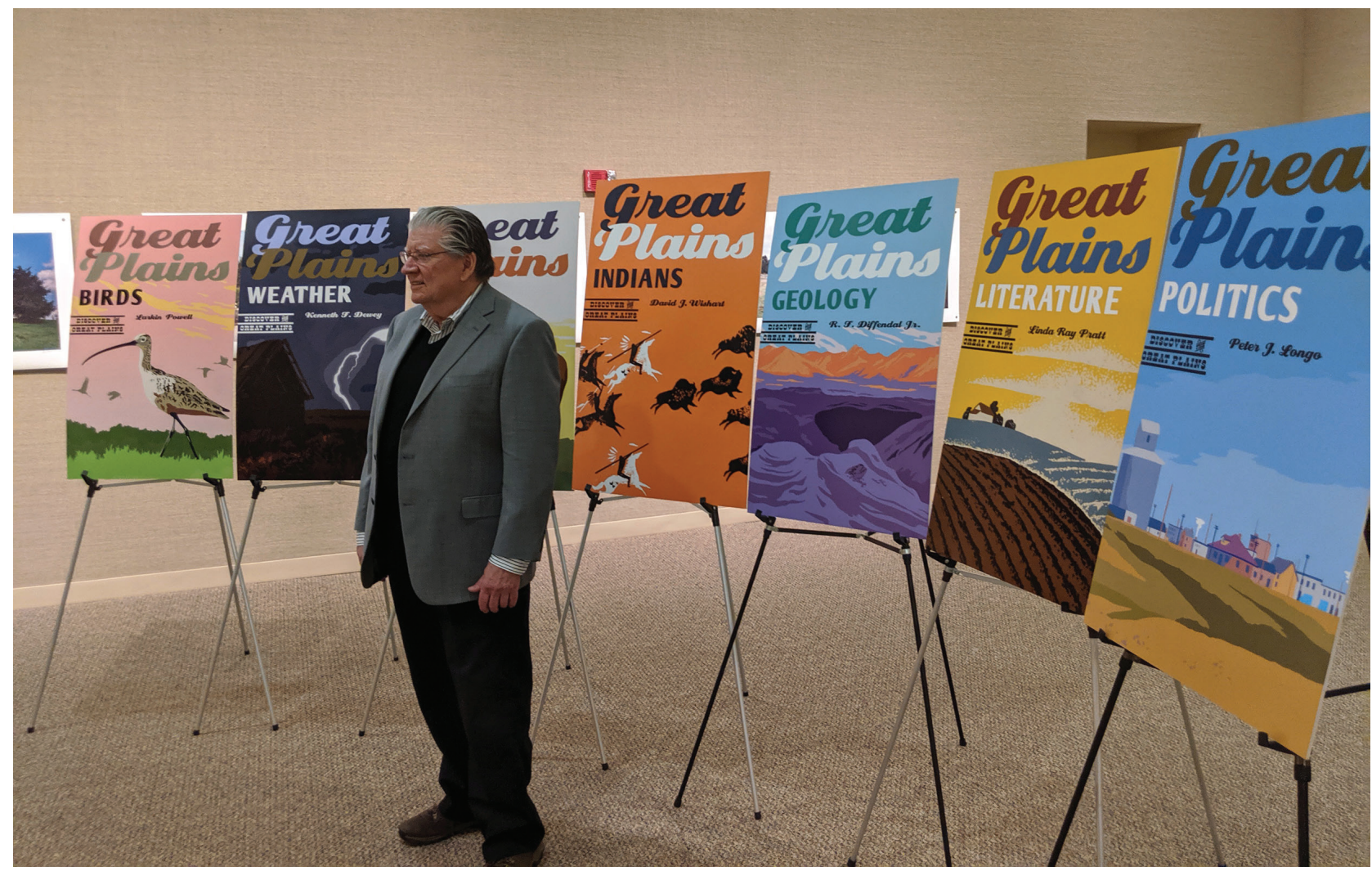

First, the African imperative brought experts to and from southwest Africa, and Namibia in particular, to Nebraska. There was so much to digest and to learn from these learned scholars. I lamented I was not a decade or two younger and might have journeyed to these plains of southwest Africa. But others got to go, including Rick, and those experiences were shared in informal gatherings, the Center's publications, and guest lectures. That international direction was new for the Center, and Rick led the charge.

Second, close at hand was the Homestead National Monument near Beatrice, Nebraska, forty miles south of Lincoln. The beauty of Homestead National Monument was not only the preserved and hospitable place but also the marvelous homesteading records. Most Americans, and in particular most scholars, did not know the astounding civil rights history of the Homesteading Act. For the first time in North America, women could own extensive amounts of land because of the homestead law. And so might African Americans. With regional scholars, Rick supported and helped lead studies of the African American homesteading experience. This, in many ways, was a pioneering effort.
And third, the Center is now the home to graduate student research in both master's and $\mathrm{PhD}$ degree programs. These learned scholars are probing the cultural and environmental thrusts of Great Plains studies. Rick led this very important aspect of the Center, as the furthering of a new and creative scholarship is so important and fundamental. The Center has afforded new scholars a chance to have their ideas considered by the vast array of talent at the Center.

There are, of course, many more aspects to consider as a part of Rick Edwards's leadership and legacy. I have chosen to briefly concentrate on the above three. It has been a delight to get to know Rick and to appreciate the varied aspects of his scholarship.

Thank you, Rick, for your strong leadership and intellect at our Center for Great Plains Studies, Nebraska's shining jewel of learning.

Sincerely,

John R. Wunder

Emeritus Professor

Department of History, UNL 